Research Article

\title{
Review on Public Health Services among School- Going Adolescents in Kerala
}

\author{
Lucy George', Sabitha N², Rehna Rehman ${ }^{3}$, Libu GK ${ }^{4}$
}

${ }^{1}$ Research Scholar, ${ }^{2} \mathrm{HOD}$ and Associate Professor, Department of Nutrition and Dietetics, Vellalar College for Women, Erode, Tamil Nadu, India.

${ }^{3}$ Resident, Department of Community Medicine Trivandrum Medical College.

${ }^{4}$ Associate Professor, Department of Community Medicine Trivandrum.

DOI: https://doi.org/10.24321/2349.2880.202010

\section{I $\quad \mathbf{N} \quad \mathbf{F} \quad \mathbf{O}$}

\section{Corresponding Author:}

Lucy George, Department of Nutrition and Dietetics, Vellalar College for Women, Erode-638012, Tamil Nadu, India.

E-mail Id:

publichealth10@gmail.com

Orcid Id:

https://orcid.org/0000-0001-7358-3671

How to cite this article:

George L, Sabitha N, Rehman R, Libu GK. Review on Public Health Services among School-Going Adolescents in Kerala. Ind J Youth Adol Health 2020; 7(2): 23-27.

Date of Submission: 2020-08-22

Date of Acceptance: 2020-09-14

\section{$\begin{array}{lllllllllllllll}\mathbf{A} & \mathbf{B} & \mathbf{S} & \mathbf{T} & \mathbf{R} & \mathbf{A} & \mathbf{C} & \mathbf{T}\end{array}$}

Background: Global investment in adolescent health is crucial. Adolescents aged 10-19 years constitute around one sixth of the world's population, account for $6 \%$ of the global burden of disease and injury, and suffer over 1.2 million deaths each year. India is home to 253 million adolescents, accounting for $20.9 \%$ of the country's population.

Methods: The study was cross sectional and implemented in government and government aided schools in central Kerala, Pathanamthitta district. Study assessed the public health services availed in the type of schools. Total 869 schools going adolescent selected from class $5^{\text {th }}$ to $12^{\text {th }}$ standard and the age group between $10-18$ years across the 20 schools among government and government aided school in rural, urban and semi-urban areas. Selected random sample of 50 respondents in each classes and self-administrated questionnaire were distributed.

Result: Public health services provided by schools to the adolescents were studied and it was revealed that $86.8 \%$ of adolescents were provided with iron tablets, $91.7 \%$ de-worming completed. School authorities were not engaging students in anaemia education and less than half $44.6 \% .27 .9 \%$ had their blood test done last five years. Twothird of the students $59.1 \%$ said that there were timely health visits by the health professionals. On account of supplementary nutrition $48.2 \%$ agreed on proper supply of cooked food within the school, Moreover $70 \%$ girls said anthropometric measurements were taken during health visits.

Conclusion: The study found the need to improve adolescent public health services periodic health check-up, strengthening the school monitoring system to ensure the health, nutrition and wellbeing in largely to the aided and governments schools. Priority has to be given for improving mental health, knowledge about contraception and school retention.

Keywords: Public Health Services, Mental Health, Under-Nutrition, Violence, Adolescent Health 


\section{Introduction}

Adolescence is a period of dynamic brain development and complex interaction with the social environment shaping the capabilities an individual takes forward into adult life. ${ }^{1}$ Adolescence period in human growth and development occurs after childhood and before adulthood, between 10 to 19 years of age. ${ }^{2}$ It is a transitional stage of physical, physiological and psychological development from puberty to legal adulthood. During this period, an individual acquires physical, emotional, cognitive, social, and economic resources that are the foundation for health and well-being in later life. ${ }^{3}$ The uniqueness of adolescent health problems lies in their social and behavioural origins and also their developmental nature and multisystem need to evolve, which demand a multidisciplinary workforce. No discipline has garnered the necessary knowledge and skills to address the complex health problem of the population. ${ }^{4}$ Global investment in adolescent health is crucial as adolescents constitute around one sixth of the world's population, account for $6 \%$ of the global burden of disease and injury, and suffer over 1.2 million deaths each year. ${ }^{5}$ India has the largest adolescent population in the world, about $21 \%$ of Indian population is adolescent (about 243 million $)^{6}$ and conditions like poverty, lack of access to health care services, unsafe environments. become a major challenge for the children of this age. Individuals undergo major anthropometric and hormonal transitions in this age, approximately $15-20 \%$ of adult height, up to $60 \%$ of skeletal mass, and $50 \%$ of adult body weight is gained during the adolescent period. Anthropometric measurements, including Body Mass Index (BMI)-for-age and height-for-age, are used to monitor the changes in pubertal growth. ${ }^{7}$ Lack of nutrients-rich food during this age can impact both immediate and long-term health conditions in adolescent life wherein over nutrition, under nutrition and poor reproductive health are among the emerging public health problems, with the former increasing the risk for non-communicable diseases such as diabetes and cardiovascular disease. Anaemia is also a leading cause of morbidity among adolescents; and factors such as, nutritional deficiencies, infections, and genetic conditions. ${ }^{8}$ Recent study was conducted in Thiruvanathapuram district among adolescent girls health problems obesity $2.8 \%$, underweight $51.6 \%$, premenstrual symptoms $83 \% .9$ Kerala, a southwestern state of 33.3 million people has consistently been a prominent outlier with better health outcomes in a number of areas compared to most states in India. In 2011, Kerala attained the highest Human Development Index of all Indian states based on its performance in key measures. The health gains made in Kerala can be attributed to several factors, including strong emphasis from the state government on public health and Primary Health Care (PHC), health infrastructure, decentralized governance, financial planning, girls' education, community participation and a willingness to improve systems in response to identified gaps. $^{10}$

Despite all this public health services, it is necessary to assess the available services reaching out to the beneficiaries especially government school and government aided school adolescents; nutrition is important which includes assessment of the public health which has occurred in the school. This assessment will help and give knowledge about the problems faced by the adolescent girls at this stage and can help improve in the public health intervention programme.

\section{Material and Methods}

A cross-sectional study was conducted in rural, semi-urban and urban locals at Pathanamthitta District, Central Kerala; 20 different schools including 11 governments-aided schools and 9 government schools were selected through random sampling considering operational feasibility, 869 adolescent girls between age group of $10-18$ years took part in the survey from the selected schools.

\section{Inclusion Criteria}

Adolescent girls from the selected schools, between the specified age 10-18 groups, who were willing to participate.

\section{Exclusion Criteria}

Selected Students who were not present in school premises or who were unwilling to participate.

\section{Study Variables}

- Socio-Demographic Variables: Age, Region, Religion, Father education, Father occupation, Mother education, Mother occupation, Type of family, Services from public health personnel: Public health services that are provided by the government which include iron tablets, de-worming, anaemia education, health visits, supplementary nutrition, anthropometric measurements.

- Schools under Public Health Service: Government has started several schemes for the betterment of child health in the country, schools which are following the government schemes are monitored closely.

\section{Data Collection Procedure}

A consent form for data collection was sent to the school authorities prior to conducting study also a consent form along with a questionnaire was sent to the parent. A pretested questionnaire was distributed among the students with the help of class teacher. A questionnaire was validated one and was developed with the consent of experts in health and community level. Study was described to the students in their local language. After receiving consent from the parents, students were asked to fill the questionnaire. 


\section{Data Management}

After inspecting for accuracy and uniformity data collected through questionnaire was coded and entered in Excel sheet (Microsoft Excel 2007) and subsequently with the use of SPSS software version 16.0, data was analysed. Descriptive statistics (Frequency and percentage) were used to analyse demographic and consumption pattern whereas ChiSquare test was used to evaluate the association between government-aided schools and government schools on delivering public health schemes. Statistical significance was fixed at $P$-value $<0.05$.

\section{Result}

869 school going adolescent girls of the age group between 10-18 years from rural, semi-urban and urban schools were subjected take part in a survey after getting informed consent and questionnaire about public health services. Adolescents were segregated into 3 categories: early adolescent age (10-12 years), middle adolescent group (13-15 years) and late adolescent age (16-18 years). Students who participated in the study were from either government-aided schools (59.6\%) or government schools (40.4\%). These schools were located in different regions rural urban and semi-urban at Pathanamthitta District, central Kerala (Tables 1, 2).

Table I.Distribution of adolescent age

\begin{tabular}{|c|c|c|}
\hline $\begin{array}{c}\text { Age of the adolescents in } \\
\text { (Years ) }\end{array}$ & Frequency & Percentage \\
\hline early adolescent (10-12) & 164 & 18.9 \\
\hline Middle adolescent (13-15) & 421 & 48.4 \\
\hline Late adolescents (16-18) & 284 & 32.7 \\
\hline Total & 869 & 100 \\
\hline
\end{tabular}

Table 2.Distribution of type of school

\begin{tabular}{|c|c|c|}
\hline School category & Frequency & Percentage \\
\hline Government Aided School & 518 & 59.6 \\
\hline Government school & 351 & 40.4 \\
\hline Total & 869 & 100 \\
\hline
\end{tabular}

Socio-demographic profile of the participants: Table 3 depicts socio-demographic profile of the adolescents based on which around half of the participants school located (52\%) were inhabitant to rural region. Kerala a state with highest literacy rate; it was found that majority of the father's education of the adolescents $80.9 \%$ was from high school trailed by middle $10.4 \%$, graduate $\&$ above $3.9 \%$ and $4.8 \%$ were not known. With this the employment of father's majorly fall under skilled profession, sequenced with clerical \& shop-owners $13.8 \%$, semi profession $2.5 \%$, and $4.5 \%$ were unaware of their professions which included unemployment. Female or mothers education in Kerala was vastly $(83.5 \%)$ under high school grouping. Results based on type of family adolescents it was found out that majority belonged to nuclear families.

Table 3.Socio demographic characteristics

\begin{tabular}{|c|c|c|}
\hline \multicolumn{2}{|c|}{ Description } & $\mathbf{N}$ \\
\hline \multirow{3}{*}{ Region } & Rural & $452(52.0)$ \\
\hline & Urban & $284(32.7)$ \\
\hline & semi urban & $133(15.3)$ \\
\hline \multirow{3}{*}{ religion } & Hindu & $496(57.1)$ \\
\hline & Christian & $324(37.3)$ \\
\hline & Muslim & $49(5.6)$ \\
\hline \multirow{4}{*}{$\begin{array}{c}\text { Father } \\
\text { education }\end{array}$} & Middle & $90(10.4)$ \\
\hline & High school & 703 (80.9) \\
\hline & Graduate \&above & 34 (3.9) \\
\hline & Not known & $42(4.8)$ \\
\hline \multirow{4}{*}{$\begin{array}{c}\text { Father } \\
\text { occupation }\end{array}$} & Skilled \&others & $685(78.8)$ \\
\hline & Clerical \& Shopowners & $120(13.8)$ \\
\hline & semi profession & $22(2.5)$ \\
\hline & Not known & $42(4.5)$ \\
\hline \multirow{4}{*}{$\begin{array}{c}\text { Mother } \\
\text { education }\end{array}$} & Middle & $43(4.9)$ \\
\hline & High school & $726(83.5)$ \\
\hline & Graduate \&above & $82(9.4)$ \\
\hline & Not known & $18(2.1)$ \\
\hline \multirow{4}{*}{$\begin{array}{c}\text { Mother } \\
\text { occupation }\end{array}$} & Housewife & $594(68.4)$ \\
\hline & Skilled \&others & $158(11.3)$ \\
\hline & $\begin{array}{c}\text { Clerical \& } \\
\text { Semiprofession }\end{array}$ & $98(11.3)$ \\
\hline & Not known & $19(2.2)$. \\
\hline \multirow{2}{*}{$\begin{array}{l}\text { Type of } \\
\text { family }\end{array}$} & Extended nuclear & $225(25.9)$ \\
\hline & Nuclear & $644(74.1)$ \\
\hline
\end{tabular}

Services from public health personnel: Table 4, illustrates public health services provided by schools to the adolescents and it was revealed that $86.8 \%$ of adolescents were provided with Iron tablets; $91.7 \%$ of school going students had their de-worming completed. School authorities were not engaging students in anaemia education and less than half $44.6 \%$ were getting anaemia related education. No regular blood check-up camps were organized and nearly quarter of the students $27.9 \%$ had their blood test done. Two-third of the students $59.1 \%$ said that there were timely health visits by the health professionals. On account of supplementary nutrition $48.2 \%$ agreed on proper supply of cooked food within the school, Moreover $70 \%$ girls said anthropometric measurements were taken during health visits. 
Table 4.Description of public health service

\begin{tabular}{|c|c|c|}
\hline Services & Frequency & Percentage \\
\hline $\begin{array}{c}\text { Iron Tablets given } \\
\text { Yes } \\
\text { No }\end{array}$ & $\begin{array}{l}754 \\
115 \\
\end{array}$ & $\begin{array}{l}86.8 \\
13.1\end{array}$ \\
\hline $\begin{array}{c}\text { Deworming done } \\
\text { Yes } \\
\text { No }\end{array}$ & $\begin{array}{c}797 \\
72 \\
\end{array}$ & $\begin{array}{c}91.7 \\
8.3\end{array}$ \\
\hline $\begin{array}{c}\text { Anemia education } \\
\text { Yes } \\
\text { No }\end{array}$ & $\begin{array}{l}388 \\
481\end{array}$ & $\begin{array}{l}44.6 \\
55.4\end{array}$ \\
\hline $\begin{array}{c}\text { Blood tests on students } \\
\text { Yes } \\
\text { No }\end{array}$ & $\begin{array}{l}235 \\
634\end{array}$ & $\begin{array}{l}27.9 \\
73.0 \\
\end{array}$ \\
\hline $\begin{array}{c}\text { Health visits } \\
\text { Yes } \\
\text { No }\end{array}$ & $\begin{array}{l}514 \\
355\end{array}$ & $\begin{array}{l}59.1 \\
40.9\end{array}$ \\
\hline $\begin{array}{c}\text { Supplementary nutrition } \\
\text { Yes } \\
\text { No }\end{array}$ & $\begin{array}{l}419 \\
450\end{array}$ & $\begin{array}{l}48.2 \\
51.8\end{array}$ \\
\hline $\begin{array}{c}\text { Anthropometry } \\
\text { measurement } \\
\text { Yes } \\
\text { No }\end{array}$ & $\begin{array}{l}608 \\
261\end{array}$ & $\begin{array}{l}70.0 \\
30.0\end{array}$ \\
\hline
\end{tabular}

Table 5, illustrates the associated factors in aided school and government schools. Many of the variables were found to be closely associated with type of school. Consumption of deworming tablets, education given anaemia, periodic blood test were done; p0.002 p-0.001 and p 0.001 respectively. Adolescent public health service health services, distribution of iron tablet deworming, education of anaemia, frequent blood test teachers friendly also strongly significantly associated with school category.

\section{Disscussion}

Public health services play a major role in life of adolescents who are unable to afford education in exorbitant settings. If executed properly these services can fulfil the basic requirements of the children, but to monitor the proceeding of these services the parent of the child has to be educated and aware of the ambience and facilities in school, as seen in the outcome, the education of the parent was not a concern but due to their involvement in their own work and busy schedules children were neglected; mothers on other hand were educated and professionally majority of them were involved in house hold work even then the students were not completely benefitted from the health services provided by the government. Evidence revel that nutritional requirement in adolescents in high effect of which they require diets filled with proteins, vitamins, calcium, lodine, phosphorous and iron. This increased demand is a result of second growth spurt and increased physical activity. ${ }^{11}$ Insufficient nutrient intake can lead to stunted growth and deferred sexual maturation. ${ }^{12}$

The state government has been sown the starting of school health programme in 2007 one of the largest school in Kerala. The clinic provided one doctor, nurse and attendant for receiving students patient who were given the appropriate treatment and quality services. Impact of these services led government to extend these services to other schools of the state planning to culminate in implementation of the special school health programme. Thus, a renovated School Health Program was launched in 2009 in $10 \%$ of Government and Government Aided schools in Kerala. The programme was envisaged cover all Government \& Aided schools of the state in a phased manner. ${ }^{13}$

Health of pupils can affect the cognitive, sensory and connectedness of a child to education. ${ }^{14}$

Another obstacle is unavailability of resources like finance,

Table 5.Association of public health service by government and government Aided school

\begin{tabular}{|c|c|c|c|c|c|c|}
\hline \multirow{2}{*}{\multicolumn{2}{|c|}{$\begin{array}{l}\text { Public health service and socio- } \\
\text { demographic descriptive }\end{array}$}} & \multicolumn{3}{|c|}{ School category } & \multirow{2}{*}{$x 2$} & \multirow{2}{*}{$\begin{array}{c}95 \% \mathrm{Cl} \\
\mathrm{p}\end{array}$} \\
\hline & & Aided school & Government school & Total & & \\
\hline \multirow{2}{*}{ Iron tablet given } & Yes & $451(87.1)$ & $303(86.3)$ & & \multirow{2}{*}{.100} & \multirow{2}{*}{$\begin{array}{c}1.06(.716-1.58) \\
p 0.752\end{array}$} \\
\hline & no & $67(12.7)$ & $48(13.7)$ & & & \\
\hline \multirow{2}{*}{ Deworming done } & Yes & $463(89.4)$ & 334 (95.2) & & \multirow{2}{*}{9.18} & \multirow{2}{*}{$\begin{array}{c}0.428(0.244-0.751) \\
\text { p0.002 }\end{array}$} \\
\hline & no & $55(10.6)$ & $17(4.8)$ & & & \\
\hline \multirow{2}{*}{ Education of anemia } & Yes & 205 (39.6) & $183(52.1)$ & & \multirow{2}{*}{13.35} & \multirow{2}{*}{$\begin{array}{c}0.601(0.457-0.790) \\
p-0.001\end{array}$} \\
\hline & no & $313(60.4)$ & 168 (47.9) & & & \\
\hline \multirow{2}{*}{$\begin{array}{l}\text { Periodic blood test } \\
\text { done }\end{array}$} & Yes & 77 (14.9) & $158(45.0)$ & & \multirow{2}{*}{96.39} & \multirow{2}{*}{$\begin{array}{c}0.231(0.155-0.294) \\
\text { p0.001 }\end{array}$} \\
\hline & no & $441(85.1)$ & $193(55.0)$ & & & \\
\hline
\end{tabular}


material and man-power for the services instead of numerous programs available, the reachability to the target group is still not possible. Moreover, service providers experience excessive work load as no separate manpower is allotted to adolescent's health services. Children themselves have petite knowledge about the necessity of the health services; due to emotional immaturity they feel jittery in revealing personal matters to unknown person, so they themselves become the hindrance in availing health services. ${ }^{9}$ In this study, there was no much widening gap between government school service and aided school service provided by the government but there are other equally worried about the health appraisal form has to develop at the time of admission. This would be helping to routine inspection and screening for children at the $360^{\circ}$ level.

\section{Conclusion}

The study concluded that, to achieve the adolescent health and wellbeing, school is the major platform as it can play a tremendous role to enhance the public health service available in India. Study focussed on available service in the government schools and government aided schools and the respondent's socio-demographic factors also that influence the adolescent health. Local authorities like schools, Panchayat and PHC centre also can ensure the programme coverage; it is also needed to periodically assess their health issues and monitor properly for availing health services provided by India. This data may help in finding the gap or to improve the basic amenities and care provided by the government for school adolescent health programme. Effective policy with good monitoring and evaluation is imperative in ensuring adequate and optimal implementation of school health services in all schools in Kerala.

\section{Conflict of Interest: None \\ References}

1. Blakemore SJ, Mills KL. Is adolescence a sensitive period for sociocultural processing?. Annual review of psychology 2014; 65: 187-207.

2. WHO Adolescent Development. WHO.Availablefrom: http://www.who.int/maternal_child_adolescent/ topics/adolescence/dev/en/. [Last cited on $2016 \mathrm{Jul}$ 14].Back to cited text no.1.

3. Patton GC, Sawyer SM, Santelli JS, Ross DA, Afifi R, Allen NB et al. Our future: a Lancet commission on adolescent health and wellbeing. The Lancet 2016; 387(10036): 2423-2478.

4. Blum R, Smith M. Training of health professionals in adolescent health care: study group report. Journal of Adolescent Health Care 1988; 9(6): S46-S50.

5. Kuruvilla S, Bustreo F, Kuo T, Mishra CK, Taylor K, Fogstad
$H$, et al. The Global strategy for women's, children's and adolescents' health (2016-2030): a roadmap based on evidence and country experience. Bulletin of the World Health Organization 2016; 94(5): 398.

6. Handbook S. Rashtriya Kishor Swasthya Karyakram. Adolescent Health Division Ministry of Health and Family Welfare Government of India. 2014.

7. Spear BA. Adolescent growth and development. Journal of the Academy of Nutrition and Dietetics, S23. 2002.

8. Kassebaum NJ, Jasrasaria R, Naghavi M, Wulf SK, Johns $\mathrm{N}$, Lozano $\mathrm{R}$ et al. A systematic analysis of global anemia burden from 1990 to 2010. Blood 2014; 123(5),:615624.

9. Nazeema Beevi P, Manju L, Anil Bindhu. A study of adolescent health problems in a rural school in Thiruvanthapuram district, Kerala, India International Journal of Community Medicine and Public Health Beevi NP et al. Int J Community Med Public Health 2017; 4(1): 100-103. http://www.ijcmph.com.

10. Government of India Planning Commission. Twelfth Five Year Plan 2012-17. Availablefrom:http://www. planningcommission.nic.in/plans/planrel/fiveyr/ welcome.html.

11. Sivagurunathan C, Umadevi R, Rama R, Gopalakrishnan S. Adolescent health: present status and its related programmes in India. Are we in the right direction?. Journal of clinical and diagnostic research: JCDR 2015; 9(3): LE01.

12. Stang J, Story M. Guidelines for adolescent nutrition services. Minneapolis, MN: Center for Leadership. Education and Training in Maternal and Child Nutrition, Division of Epidemiology and Community Health, School of Public Health. University of Minnesota 2005; 9: 101-108.

13. National health mission, Arogya Keralam Office of the Mission Director NRHM. https://arogyakeralam.gov. in/contact/.

14. Basch CE. Healthier Students Are Better Learners: AMissing Link in School Reforms to Close the Achievement Gap. Campaign for Educational Equity Teachers College, Columbia University, March 2010. 